\title{
Integrated Model of a Family Approach and Local Support in Tuberculosis Case Finding Efforts in People with HIV/AIDS
}

\author{
Erni Astutik1 ${ }^{1}$, Chatarina Umbul Wahyuni ${ }^{*}$, Imelda F E Manurung2 ${ }^{2}$, Geofrey Ssekalembe ${ }^{3}$
}

\begin{abstract}
${ }^{1}$ Department of Epidemiology, Biostatistics, Population Studies, and Health Promotion, Faculty of Public Health, Universitas Airlangga, Surabaya, Indonesia, ${ }^{2}$ Department of Epidemiology, Faculty of Public Health, Universitas Nusa Cendana, Kupang, Indonesia, ${ }^{3}$ Elizabeth Glaser Pediatric AIDS Foundation, Uganda
\end{abstract}

\begin{abstract}
The human immunodeficiency virus (HIV) remains a major global public health problem. People with HIV/acquired immune deficiency syndrome (AIDS) are more susceptible to opportunistic infections such as tuberculosis (TB). Therefore, families and community leaders need to help monitor people living with HIVIAIDS (PLWHA). This study aimed to analyze an integrated family approach and local support model to detect TB cases in PLWHA. This study used a case-control study in Kupang City, East Nusa Tenggara Province, in July 2020. The sample comprised 100 people (50 PLWHA with TB case and 50 controls) using total random sampling. The variables related to TB case finding in PLWHA were family employment status, duration of HIVIAIDS, family knowledge of $\mathrm{TB}$, and family support. The data were analyzed using multiple logistic regression. The families with PLWHA with an extended illness duration $(\mathrm{OR}=0.81$; $95 \% \mathrm{Cl}=0.69-0.95 ; \mathrm{p}$-value $=0.01)$, families who did not work $(\mathrm{OR}=3.31 ; 95 \% \mathrm{Cl}=1.16-9.41 ; \mathrm{p}$-value $=0.025)$, families who had good knowledge $(\mathrm{OR}=$ $4.79 ; 95 \% \mathrm{Cl}=1.70-13.51 ; \mathrm{p}$-value $=0.003)$, and families who provided good support $(\mathrm{OR}=3.03 ; 95 \% \mathrm{Cl}=1.05-8.76 ; \mathrm{p}$-value $=0.04)$ were better able to detect TB in PLWHA.
\end{abstract}

Keywords: acquired immune deficiency syndrome, family approach, human immunodeficiency virus, local support, tuberculosis

\section{Introduction}

The human immunodeficiency virus (HIV) continues to be a major global public health problem. HIV has claimed nearly 33 million lives to date. The virus weakens the immune system and causes swollen lymph nodes, weight loss, fever, diarrhea, and coughing. Without treatment, HIV can also develop into a severe disease such as tuberculosis (TB). ${ }^{1} \mathrm{~TB}$ is the leading cause of acquired immune deficiency syndrome (AIDS)-related deaths. ${ }^{2,3}$

The risk of developing TB is estimated to be between 16 and 27 times greater in people living with HIV than in those not infected with HIV. In 2015, there were an estimated 10.4 million cases of TB globally, including 1.2 million $(11 \%)$ among people living with HIV. Nearly $60 \%$ of TB cases among people living with HIV were not diagnosed or treated, resulting in 390,000 TB-related deaths among people living with HIV in $2015 .{ }^{4}$ In addition, HIV coinfection has a negative impact on TB treatment outcomes. 5

In 2018, 640,000 people living with HIV were living in Indonesia, 46,000 people had new HIV infections, and 38,000 had had HIV/AIDS-related deaths. ${ }^{6}$ Indonesia

Correspondence*: Chatarina Umbul Wahyuni, Department of Epidemiology, Biostatistics, Population Studies, and Health Promotion, Faculty of Public Health, Universitas Airlangga, Surabaya, Indonesia, Email: chatrin03@yahoo.com, Phone: +6281803298525 has the second-highest number of TB cases in the world. ${ }^{7}$ The incidence of TB in Indonesia in 2018 was 316 per 100,000 population, and the death rate was 40 per 100,000 population. ${ }^{8}$ In addition, the incidence of HIVTB prevalence was $2.5 \%$.

Kupang City, located in East Nusa Tenggara, Indonesia, has a high number of HIV/AIDS cases. ${ }^{9}$ This raises the risk of opportunistic TB infection in people living with HIV/AIDS (PLWHA) and the burden on the local government. ${ }^{10}$ PLWHA must have access to HIV and TB health services and treatment for HIV and TB infection as part of the universal access to prevention and care. TB prevention requires preventive interventions for HIV and TB infection. ${ }^{11}$ It is essential that care programs for PLWHA include aspects of TB prevention to reduce the mortality rate of PLWHA.

According to Lawn and Churchyard's study, HIV-TB remains a major global health challenge. ${ }^{12}$ Furthermore, the stigma of HIV-TB needs to be overcome, especially in areas with a high HIV prevalence. ${ }^{13}$ To support TB prevention programs in PLWHA, it is necessary to obtain support from various parties, including health workers

Received : April 19, 2021

Accepted : September 13, 2021

Published: November 29, 2021 
and the families and community leaders of PLWHA. Previous study has shown that passive case finding for TB alone is not sufficient. ${ }^{14}$ Active case finding in TB contact households should be considered to improve TB and HIV case detection. ${ }^{15}$ The results of other studies have also suggested that the factors that influence the detection of active TB cases are the health system, society, and individuals. ${ }^{16}$ Active case findings can contribute to the target End TB strategy. ${ }^{17,18}$ Family has a crucial role to play in supporting PLWHA when seeking and obtaining treatment. A study conducted in China found that community-based active case finding is significant for high-risk groups. ${ }^{19}$ In contrast, another study in Papua New Guinea determined that community-based active case finding and the initiation of TB treatment with limited resources and remote areas can have a good impact. ${ }^{20}$ This study aimed to analyze the relationship between the role of the family and local support in TB case finding efforts for PLWHA in Kupang City. The results of this study were expected to help the Indonesian Government in its efforts to reduce the burden and mortality of PLWHA.

\section{Method}

This case-control study was conducted in July 2020 in Kupang City, East Nusa Tenggara Province, Indonesia. The population of this study comprised PLWHA who were registered at the referral hospital in Kupang City. The number of PLWHA who were recorded as being on antiretroviral therapy was 1,500 . The sample selection procedure began by recording all HIV/AIDS patients from 2016 to 2020 (e.g., 1,500 people). HIV/AIDS patients who had TB were selected to be in the case group. Among all the HIV/AIDS patients, 61 had TB. However, only 50 people were still alive and had addresses that the authors could find.

The controls were selected from the HIV/AIDS population who did not have TB, and 50 people were randomly selected. The patients who had died and whose home addresses were not found were excluded from the list of eligible participants. From the selected case and control groups, the authors contacted the families of each patient to serve as study subjects (respondents). Therefore, the case group consisted of families with PLWHA who had TB, and the controls were families with PLWHA who did not have TB.

The primary data were collected using a questionnaire. Enumerators who had been trained before conduct the study carried out the data collection. The outcome variable of this study was the TB case finding efforts, finding TB cases in PLWHA, and not finding TB cases in PLWHA. The independent variables included the characteristics of the family of the PLWHA (relationship with the PLWHA, sex, employment status, age, and educa- tion), local support characteristics (gender, age, and length of time spent supporting PLWHA), the characteristics of the PLWHA (gender, age, length of time with HIV/AIDS), family knowledge about TB, health literacy, family support, service leadership, social capital, and knowledge of PLWHA about TB.

Regarding family characteristics, the relationship variables were categorized as the family of the PLWHA (husband/wife, parents, relatives) and people who were not family (other people). Gender included male and female. Employment was categorized as working (government employee, self-employed) and not working (not working, father, or housewife). Education level was categorized into low (not educated, elementary school, junior high school), medium (senior high school), and high (college). Age was measured according to the respondent's age in years.

For local support, gender was categorized as male and female. The person providing local support was measured according to the respondent's age at that time, and the length of time spent supporting the PLWHA was calculated based on the length of time the person had provided local support to the PLWHA to date. The characteristics of the PLWHA included gender (male and female), the age of the PLWHA at the time of the interview, and the length of time living with HIV/AIDS based on the time of the first diagnosis by health workers. Family knowledge about TB, family health literacy, and family support was described as good or bad, as were the leadership provided by the family (local support and social capital support). The PLWHA's knowledge of TB and coronavirus disease 2019 (COVID-19) was also categorized as good or bad. All the variables were categorized based on their median values.

The data were analyzed using univariable, bivariable, and multivariable analysis. The univariable analysis was used to describe the measured variables. The authors used the Chi-square test and independent t-test to analyze the relationships between the independent variables and the TB case finding. All the variables with a p-value $<0.25$ in the bivariable analysis were included in the initial multivariable model. A backward elimination procedure was used to identify the factors independently associated with a TB case finding in PLWHA. In the final model, the variables with a $p$-value $<0.05$ were considered statistically significant.

\section{Results}

Eighty-one percent of the respondents were families with a blood relationship with PLWHA, $62 \%$ of the respondents were women, $61 \%$ were working, and $62 \%$ had moderate education. The average age was 43.09 years with a standard deviation of 13.45 years. In addition, $54 \%$ of the local support was female, with an aver- 
Table 1. Family Characteristics, Local Support, and People Living with HIV/AIDS

\begin{tabular}{|c|c|c|c|c|c|}
\hline Variable & Category & $\mathbf{n}$ & $\%$ & Mean & SD \\
\hline \multicolumn{6}{|l|}{ Characteristics of PLWHA families } \\
\hline \multirow[t]{2}{*}{ Relationship with PLWHA } & Families & 81 & 81 & & \\
\hline & Family but not blood-related & 19 & 19 & & \\
\hline \multirow[t]{2}{*}{ Sex } & Male & 38 & 38 & & \\
\hline & Female & 62 & 62 & & \\
\hline \multirow[t]{2}{*}{ Family employment status } & Working & 61 & 61 & & \\
\hline & Not working & 39 & 39 & & \\
\hline Age (years) & & & & 43.09 & 13.45 \\
\hline \multirow[t]{3}{*}{ Family education } & Lower & 38 & 38 & & \\
\hline & Medium & 62 & 62 & & \\
\hline & Higher & 0 & 0 & & \\
\hline \multicolumn{6}{|l|}{ Characteristics of local support } \\
\hline \multirow[t]{2}{*}{ Sex } & Male & 46 & 46 & & \\
\hline & Female & 54 & 54 & & \\
\hline Age (years) & & & & 48.25 & 13.27 \\
\hline Length of time supporting PLWHA (years) & & & & 2.62 & 1.75 \\
\hline \multicolumn{6}{|l|}{ Characteristics of PLWHA } \\
\hline \multirow[t]{2}{*}{ Sex } & Male & 46 & 46 & & \\
\hline & Female & 54 & 54 & & \\
\hline Age (years) & & & & 35.11 & 8.69 \\
\hline HIV/AIDS duration (years) & & & & 4.38 & 3.62 \\
\hline \multicolumn{6}{|l|}{ Family and local support } \\
\hline \multirow[t]{2}{*}{ Family knowledge of $\mathrm{TB}$} & Good & 59 & 59 & 9.270 & 2.06 \\
\hline & $\mathrm{Bad}$ & 41 & 41 & & \\
\hline \multirow[t]{2}{*}{ Health literacy of families } & Good & 57 & 57 & 1.300 & 1.16 \\
\hline & $\mathrm{Bad}$ & 43 & 43 & & \\
\hline \multirow[t]{2}{*}{ Family support } & Good & 58 & 58 & & \\
\hline & Bad & 42 & 42 & 0.870 & 1.19 \\
\hline \multirow{2}{*}{ Leadership providing local support } & Good & 52 & 52 & & \\
\hline & $\mathrm{Bad}$ & 48 & 48 & 13.160 & 7.76 \\
\hline \multirow[t]{2}{*}{ Family-supported social capital } & Good & 56 & 56 & & \\
\hline & Bad & 44 & 44 & 10.590 & 5.22 \\
\hline \multicolumn{6}{|l|}{ Knowledge of PLWHA } \\
\hline \multirow[t]{2}{*}{ PLWHA knowledge of TB } & Good & 45 & 45 & & \\
\hline & $\mathrm{Bad}$ & 55 & 55 & 9.810 & 1.54 \\
\hline
\end{tabular}

Notes: PLWH = People Living with HIV/AIDS; SD = Standard Deviation

age age of $48.25( \pm 13.27)$ years and an average length of time supporting the PLWHA of $2.62( \pm 1.75)$ years. More than half of the PLWHA (54\%) were female. The mean age was $35.11( \pm 8.69)$ years, and the average length of time living with HIV/AIDS was $4.38( \pm 3.62)$ years (Table 1).

Regarding of family knowledge about TB, $41 \%$ had bad knowledge, $43 \%$ had bad family health literacy, and $42 \%$ of the PLWHA received poor family support. Concerning local support, $48 \%$ of the local support provided by leadership was poor, and $44 \%$ of the local support social capital was poor. In addition, the knowledge about the COVID-19 among the family and local support and PLWHA were very good at $72 \%$ and $68 \%$, respectively. However, $55 \%$ of the PLWHA had poor knowledge about TB (Table 1).

The distribution of respondent characteristics based on cases and controls groups can be seen in Table 2 and 3. The family of PLWHA who were able to find TB cases and who were not were $74 \%$ and $88 \%$, respectively. Of
$74 \%$ of the family of PLWHA who were able to find TB cases, $68 \%$ succeeded in finding it in women. While the ones who were not able to find TB cases but were women were $56 \%$. The PLWHA families who were able to find TB cases and did not find working TB were $50 \%$ and $72 \%$, respectively. In addition, PLWHA families who were able to find TB cases and had medium education were slightly larger $(66 \%)$ than PLWHA families who were unable to find $\mathrm{TB}$ cases and had medium education $(58 \%)$. The PLWHA families who were able to find TB cases were on average $40.54 \pm 11.58$ years old and PLWHA families who were unable to find TB cases were $45.64 \pm 14.77$ years old on average. PLWHA families who were able to find TB cases had an average length of stay of $2.58 \pm 1.50$ years and those who were unable to find TB cases had an average length of stay of $2.66 \pm 1.98$ years.

PLWHA families who are able to find TB cases have higher knowledge (76\%) compared to PLWHA families who are unable to find TB cases (42\%). PLWHA families 
Table 2. Bivariate Analysis of the Independent Variables and TB Case Finding Using a Chi-Square Test

\begin{tabular}{|c|c|c|c|c|c|c|c|c|c|}
\hline \multirow{2}{*}{ Variable } & \multirow{2}{*}{ Category } & \multicolumn{2}{|c|}{ Finding TB } & \multicolumn{2}{|c|}{ Not finding TB } & \multirow{2}{*}{ OR } & \multicolumn{2}{|c|}{$\mathbf{9 5} \% \mathrm{CI}$} & \multirow{2}{*}{ p-value } \\
\hline & & $\mathbf{n}$ & $\%$ & $\mathbf{n}$ & $\%$ & & Lower & Upper & \\
\hline \multicolumn{10}{|l|}{ Characteristics of PLWHA families } \\
\hline \multirow[t]{2}{*}{ Relationship with PLWHA } & Family but not blood-related & 13 & 26 & 6 & 21 & 2.58 & 0.89 & 7.45 & 0.126 \\
\hline & Family & 37 & 74 & 44 & 88 & & & & \\
\hline \multirow[t]{2}{*}{ Sex } & Male & 16 & 32 & 22 & 44 & 0.60 & 0.24 & 1.48 & 0.303 \\
\hline & Female & 34 & 68 & 28 & 56 & & & & \\
\hline \multirow{2}{*}{ Employment status } & Not working & 25 & 50 & 14 & 28 & 2.57 & 1.12 & 5.90 & 0.04 \\
\hline & Working & 25 & 50 & 36 & 72 & & & & \\
\hline \multirow[t]{2}{*}{ Education } & Low & 17 & 34 & 21 & 42 & 0.71 & 0.32 & 1.60 & 0.537 \\
\hline & Medium & 33 & 66 & 29 & 58 & & & & \\
\hline \multicolumn{10}{|l|}{ Characteristics of local support } \\
\hline \multirow[t]{2}{*}{ Sex } & Male & 22 & 44 & 24 & 48 & 0.85 & 0.39 & 1.87 & 0.841 \\
\hline & Female & 28 & 56 & 26 & 52 & & & & \\
\hline \multicolumn{10}{|l|}{ Characteristics of PLWHA } \\
\hline \multirow[t]{2}{*}{ Sex } & Male & 24 & 48 & 22 & 44 & 1.18 & 0.54 & 2.58 & 0.841 \\
\hline & Female & 26 & 52 & 28 & 56 & & & & \\
\hline \multicolumn{10}{|l|}{ Family and local support } \\
\hline \multirow[t]{2}{*}{ Health literacy of family } & Good & 27 & 54 & 30 & 60 & 0.78 & 0.35 & 1.73 & 0.686 \\
\hline & Bad & 23 & 46 & 20 & 40 & & & & \\
\hline \multirow[t]{2}{*}{ Family support } & Good & 37 & 74 & 21 & 42 & 3.93 & 1.69 & 9.15 & 0.002 \\
\hline & Bad & 13 & 26 & 29 & 58 & & & & \\
\hline \multirow{2}{*}{ Leadership providing local support } & Good & 25 & 50 & 27 & 54 & 0.85 & 0.39 & 1.87 & 0.841 \\
\hline & Bad & 25 & 50 & 23 & 46 & & & & \\
\hline \multirow{2}{*}{ Family-supported social capital } & Good & 26 & 52 & 30 & 60 & 0.72 & 0.33 & 1.60 & 0.546 \\
\hline & Bad & 24 & 48 & 20 & 40 & & & & \\
\hline \multirow[t]{2}{*}{ Family knowledge of COVID-19 } & Good & 35 & 70 & 37 & 74 & 0.82 & 0.34 & 1.97 & 0.824 \\
\hline & Bad & 15 & 30 & 13 & 26 & & & & \\
\hline \multicolumn{10}{|l|}{ Knowledge of PLWHA } \\
\hline \multirow[t]{2}{*}{ PLWHA knowledge of TB } & Good & 30 & 60 & 15 & 30 & 3.50 & 1.53 & 8.01 & 0.005 \\
\hline & Bad & 20 & 40 & 35 & 70 & & & & \\
\hline \multirow[t]{2}{*}{ PLWHA knowledge of COVID-19 } & Good & 35 & 70 & 22 & 66 & 1.20 & 0.52 & 2.79 & 0.83 \\
\hline & Bad & 15 & 30 & 17 & 34 & & & & \\
\hline
\end{tabular}

Notes: PLWHA = People Living with HIV/AIDS; CI = Confidence Interval; OR = Odds Ratio

Table 3. Bivariate Analysis of the Independent Variables and TB Case Finding Using the Independent t-Test $(n=50)$

\begin{tabular}{|c|c|c|c|c|c|}
\hline Variable & Category & Mean & SD & SE & p-value \\
\hline \multirow[t]{2}{*}{ Family age } & Finding ТВ & 40.54 & 11.58 & 1.64 & \multirow[t]{2}{*}{0.058} \\
\hline & Not finding TB & 45.64 & 14.77 & 2.09 & \\
\hline \multirow[t]{2}{*}{ Local support age } & Finding ТВ & 44.60 & 15.19 & 2.15 & \multirow[t]{2}{*}{0.006} \\
\hline & Not finding TB & 51.90 & 9.88 & 1.40 & \\
\hline \multirow[t]{2}{*}{ Length of time supporting PLWHA } & Finding ТВ & 2.58 & 1.50 & 0.21 & \multirow[t]{2}{*}{0.820} \\
\hline & Not finding TB & 2.66 & 1.98 & 0.28 & \\
\hline \multirow[t]{2}{*}{ PLWHA age } & Finding TB & 35.48 & 7.37 & 1.04 & \multirow[t]{2}{*}{0.672} \\
\hline & Not finding TB & 34.74 & 9.89 & 1.40 & \\
\hline \multirow[t]{2}{*}{ HIV/AIDS duration } & Finding TB & 3.34 & 2.77 & 0.39 & \multirow[t]{2}{*}{0.004} \\
\hline & Not finding TB & 5.42 & 4.07 & 0.58 & \\
\hline
\end{tabular}

Notes: PLWHA = People Living with HIV/AIDS; SD = Standard Deviation; SE = Standard Error

who were able to find TB cases had lower health literacy (54\%) compared to PLWHA families who were unable to find TB cases $(60 \%)$.

Using a Chi-square statistical analysis, the variables having a significant relationship with the TB status of PLWHA were employment status $(\mathrm{p}$-value $=0.04)$, family knowledge about TB ( $\mathrm{p}$-value $=0.01$ ), family support ( $\mathrm{p}$-value $=0.002$ ), and knowledge of PLWHA about
TB (p-value $=0.005)($ Table 2$)$. Based on Table 3, using an independent sample t-test analysis, the variables that were significantly related to the TB status of the PLWHA were the age of local support $(\mathrm{p}$-value $=0.006)$ and length of time with TB (p-value $=0.004)$.

As shown in Table 4, after being controlled for other variables, the variables related to $\mathrm{TB}$ case finding for PLWHA were employment status, length of time living 
Table 4. Multiple Logistic Regression Analysis with TB Case Finding Outcome

\begin{tabular}{|c|c|c|c|c|c|}
\hline \multirow{2}{*}{ Variable } & \multirow{2}{*}{ Category } & \multirow{2}{*}{ AOR } & \multicolumn{2}{|c|}{$95 \%$ CI } & \multirow{2}{*}{ p-value } \\
\hline & & & Lower & Upper & \\
\hline Family employment status & $\begin{array}{l}\text { Not working } \\
\text { Working }\end{array}$ & $\begin{array}{c}3.31 \\
\text { Ref }\end{array}$ & 1.16 & 9.41 & 0.025 \\
\hline Local support age (years) & & 0.97 & 0.93 & 1.00 & 0.08 \\
\hline HIV/AIDS duration (years) & & 0.81 & 0.69 & 0.95 & 0.01 \\
\hline Family knowledge of TB & $\begin{array}{l}\text { Good } \\
\text { Bad }\end{array}$ & $\begin{array}{r}4.79 \\
\text { Ref }\end{array}$ & 1.70 & 13.51 & 0.003 \\
\hline Family support & $\begin{array}{l}\text { Good } \\
\text { Bad }\end{array}$ & $\begin{array}{r}3.03 \\
\text { Ref }\end{array}$ & 1.05 & 8.76 & 0.04 \\
\hline
\end{tabular}

Notes: PLWHA = People Living with HIV/AIDS; CI = Confidence Interval; AOR = Adjusted

Odds Ratio

with HIV/AIDS, family knowledge of TB, and family support. The PLWHA with unemployed families had a 3.31 times higher likelihood of detecting TB than those with working families $(\mathrm{OR}=3.31 ; 95 \% \mathrm{CI}=1.16-9.41$; $\mathrm{p}$ value $=0.025)$. The longer the PLWHA had HIV/AIDS, the lower the risk of finding TB in the PLWHA (OR = 0.81; 95\% CI = 0.69-0.95; -value $=0.01$ ). The PLWHA with good family knowledge was 4.79 times more likely to detect TB than those with poor family knowledge (OR $=4.79 ; 95 \% \mathrm{CI}=1.70-13.51 ; \mathrm{p}$-value $=0.003)$. The families who provided good support had a 3.03 times higher likelihood of finding TB in the PLWHA than those who provided poor family support $(\mathrm{OR}=3.03 ; 95 \% \mathrm{CI}$ $=1.05-8.76$; $\mathrm{p}$-value $=0.04$ ).

\section{Discussion}

Based on the study findings, after being controlled for other variables, the variables associated with TB case finding among PLWHA were HIV/AIDS duration, employment status of the PLWHA's family, family support, and family knowledge of TB. Living with HIV/AIDS for a more extended period, PLWHA with an unemployed family, families with good support, and PLWHA with good family knowledge of TB were better able to detect TB in the PLWHA. In this study, HIV/AIDS duration increased the risk of PLWHA getting TB. Because TB is an opportunistic infection, a study showed that it is likely to be experienced by PLWHA. ${ }^{21}$ Researchers at Dr. Kariadi Semarang Hospital found that the most opportunistic infection was TB. ${ }^{22}$ TB and HIV are closely related and often result in HIV-TB coinfection. ${ }^{22}$ This may be due to the decreased CD4 levels in PLWHA, which increases their risk of developing TB.

This study also showed that the families of PLWHA who did not work and had good family support could detect TB in the PLWHA compared to the families of PLWHA who were working. This is in line with the study findings in India indicating that the family plays a considerable role in controlling TB. ${ }^{23}$ The families of PLWHA who do not work can supervise and monitor TB treatment among PLWHA. This condition is beneficial because the long duration of TB treatment requires strong family involvement in terms of care, nutrition, and livelihood support to improve treatment adherence. ${ }^{23}$ Families who do not work are likely to see the progress of the PLWHA every day. In addition, families who support PLWHA when they know the PLWHA's condition will take the PLWHA to a healthcare facility more quickly. TB screening in PLWHA will therefore take place sooner. Social trust in family members can play an important role as both a lack of trust and support are barriers to obtaining higher TB screening rates. ${ }^{24}$

The TB treatment in PLWHA requires the intense involvement of the families of PLWHA. The factors that positively influence adherence to TB treatment are a belief in the severity of TB in the presence of HIV infection and family support. ${ }^{25}$ Families of PLWHA who do not work can supervise the treatment of PLWHA. In addition, such families can look after PLWHA at any time and monitor their progress. Therefore, it is possible that if PLWHA experiences symptoms of TB, the family would take them to healthcare services immediately.

The result showed that the families who had good knowledge of TB could detect TB in PLWHA more quickly than those with less knowledge. A study has similarly indicated that knowledge and literacy are factors that shape TB preventive behaviors. ${ }^{26}$ Efforts are needed to provide more information to the families of PLWHA so that they will be able to recognize TB symptoms in PLWHA and detect the disease early. Early detection of TB in PLWHA is very effective in reducing mortality. Comprehensive education, including the cognitive and psychological aspects of the disease, is needed for the early detection of TB. ${ }^{27}$ Knowledge about TB and lower education are related to inappropriate treatment-seeking behaviors. ${ }^{27-29}$ Families who know about and understand TB symptoms are likely to take PLWHA to seek treatment immediately. PLWHA who have a coinfection 
would therefore be evaluated immediately by a doctor and receive $\mathrm{TB}$ treatment promptly. This can help reduce the mortality rate of PLWHA.

All the procedures and instruments used in this study were validated. The field workers were also trained prior to the survey to ensure that they had a common understanding of the operational definitions of the variables. Despite these strengths, this study was subject to bias because of a case-control study design and the number of samples used is very small ( 50 respondents). The authors selected the control group from the same population as the case group. In other words, they were also PLWHA patients who were registered between 2016 and 2020, although they did not have TB. Furthermore the authors did not have data on the patients who were still alive and for whom residential addresses could not be found or those who had died. The authors then applied a simple random sampling technique to ensure that the ratio of patients and controls was 1:1. Therefore, a recommendation for future study is to have a clear sampling frame and the number of controls to be greater than the number of patients.

\section{Conclusion}

After controlling for the other variables, a long duration of HIV/AIDS, the employment status of the families of PLWHA, family support, and family knowledge of TB were associated with TB case finding in PLWHA. Living with HIV/AIDS for a more extended period, PLWHA with an unemployed family, families with good support, and PLWHA with good family knowledge of TB were better able to find TB in the PLWHA. The results of this study highlight the importance of health education among the families of PLWHA as this can help with the early detection of TB in PLWHA. In addition, the study also highlights the role of family and local support to support PLWHA. Therefore, the Indonesian Government needs to consider the role of families and local support in its program to detect TB in PLWHA.

\section{Abbreviations \\ HIV: Human Immunodeficiency Virus; AIDS: Acquired Immune Deficiency Syndrome; PLWHA: People with HIV AIDS; TB: Tuberculosis; COVID-19: coronavirus disease 2019.}

\section{Ethics Approval and Consent to Participate}

This study passed the ethical committee review of the Faculty of Public Health, Universitas Airlangga, Number 75/EA/KEPK/2020.

\section{Competing Interest}

The authors declare that there are no significant competing financial, professional, or personal interests that might have affected the performance or presentation of the work described in this manuscript.

\section{Availability of Data and Materials}

For those who need the data, please get in touch with the corresponding author of this manuscript.

\section{Authors' Contribution}

CUW contributed to the conception of the manuscript and writing the manuscript. EA contributed to writing the manuscript. Furthermore, all authors contributed to reviewing the manuscript and approved the submitted version.

\section{Acknowledgment}

The authors would like to express their sincere appreciation to the participants of this study. The authors also wish to thank AIDS Prevention Commission and Health Office in Kupang City. This study was funded by "Hibah SIMLITABMAS Dikti."

\section{References}

1. World Health Organization. HIV/AIDS; 2020.

2. Tiberi S, Carvalho ACC, Sulis G, Vaghela D, Rendon A, Mello FC de Q, et al. The cursed duet today: tuberculosis and HIV-coinfection. La Presse Medicale. 2017; 46 (2, Part 2): e23-39.

3. Pawlowski A, Jansson M, Sköld M, Rottenberg ME, Källenius G. Tuberculosis and HIV coinfection. PLoS Pathogens. 2012; 8 (2): e1002464.

4. World Health Organization. Tuberculosis and HIV; 2021.

5. Osei E, Der J, Owusu R, Kofie P, Axame WK. The burden of HIV on tuberculosis patients in the Volta region of Ghana from 2012 to 2015: implication for tuberculosis control. BMC Infectious Disease. 2017; 17 (1): 504.

6. The Joint United Nations Programme on HIV/AIDS (UNAIDS). HIV and AIDS estimates-Indonesia; 2020.

7. Kementerian Kesehatan Republik Indonesia. Profil kesehatan Indonesia tahun 2019. Kementerian Kesehatan Republik Indonesia. 2019; 42: 97 119.

8. World Health Organization. Global tuberculosis report 2019; 2019.

9. Didi A, Manurung IFE, Sir AB. Pengetahuan dan stigma keluarga ODHA terhadap orang yang terinfeksi HIV dan AIDS di Kota Kupang. Journal of Health and Behavioral Science. 2020; 2 (1): 10-7.

10. Kementerian Kesehatan Republik Indonesia. Profil kesehatan Indonesia tahun 2019; 2020.

11. Granich R, Akolo C, Gunneberg C, Getahun H, Williams P, Williams B. Prevention of tuberculosis in people living with HIV. Clinical Infectious Disease. 2010; 50 (Supplement 3): S215-22.

12. Lawn SD, Churchyard G. Epidemiology of HIV-associated tuberculosis. Current Opinion in HIV and AIDS. 2009; 4 (4): 325-33.

13. Bond V, Nyblade L. The importance of addressing the unfolding TBHIV stigma in high HIV prevalence settings. Journal of Community Applied Social Psychology. 2006; 16 (6): 452-61.

14. Ho J, Fox GJ, Marais BJ. Passive case finding for tuberculosis is not enough. International Journal of Mycobacteriology. 2016; 5 (4): 374-8.

15. Shapiro AE, Variava E, Rakgokong MH, Moodley N, Luke B, Salimi S, et al. Community-based targeted case finding for tuberculosis and HIV in household contacts of patients with tuberculosis in South Africa. American Journal of Respiratory and Critical Care Medicine. 2012; 185 
(10): 1110-6.

16. Biermann O, Lönnroth K, Caws M, Viney K. Factors influencing active tuberculosis case-finding policy development and implementation: a scoping review. BMJ Open. 2019; 9 (12): e031284.

17. Gurung SC, Dixit K, Rai B, Caws M, Paudel PR, Dhital R, et al. The role of active case finding in reducing patient incurred catastrophic costs for tuberculosis in Nepal. Infectious Disease of Poverty. 2019; 8 (1): 99.

18. Yuen CM, Amanullah F, Dharmadhikari A, Nardell EA, Seddon JA, Vasilyeva I, et al. Turning off the tap: stopping tuberculosis transmission through active case-finding and prompt effective treatment. The Lancet. 2015; 386 (10010): 2334-43.

19. Chen JO, Qiu YB, Rueda ZV, Hou JL, Lu KY, Chen LP, et al. Role of community-based active case finding in screening tuberculosis in Yunnan province of China. Infectious Diseases of Poverty. 2019; 8 (1): 92.

20. Karki B, Kittel G, Bolokon I, Duke T. Active community-based case finding for tuberculosis with limited resources: estimating prevalence in a remote area of Papua New Guinea. Asia-Pacific Journal of Public Health. 2017; 29 (1): 17-27.

21. Pribadi GS, Cahyono ABF. Characteristics and opportunistic infections of AIDS patients in East Java Province in 2018. Jurnal Berkala Epidemiologi. 2021; 9 (1): 96-104.

22. Sumiyati, Widjanarko B. Pola Konsumsi merupakan faktor yang paling dominan berpengaruh terhadap kejadian infeksi oportunistik pada ODHA di RSUP Dr. Kariadi Semarang. Jurnal Promosi Kesehatan Indonesia. 2015; 10 (2): 173-92.
23. Samal J. Family perspectives in the care and support of tuberculosis patients: an Indian context. The Journal of Association of Chest Physicians. 2017; 5 (2): 67.

24. Lau LLH, Hung N, Dodd W, Lim K, Ferma JD, Cole DC. Social trust and health seeking behaviours: a longitudinal study of a communitybased active tuberculosis case finding program in the Philippines. SSMpopulation Health. 2020; 12: 100664.

25. Gebremariam MK, Bjune GA, Frich JC. Barriers and facilitators of adherence to TB treatment in patients on concomitant TB and HIV treatment: a qualitative study. BMC Public Health. 2010; 10 (1): 1-9.

26. Novita N, Ratih P, Bayu YSN, Alvin M. Factors related to tuberculosis prevention behavior in Pendrikan Kidul Sub-District, Semarang, Central Java 2019. International Proceeding 2nd ISMoHIM 2020; 2020.

27. Putra IWGAE, Kurniasari NMD, Dewi NPEP, Suarjana IK, Duana IMK, Mulyawan IKH, et al. The implementation of early detection in tuberculosis contact investigation to improve case finding. Journal of Epidemiology and Global Health. 2019; 9 (3): 191-7.

28. Abebe G, Deribew A, Apers L, Woldemichael K, Shiffa J, Tesfaye M, et al. Knowledge, health seeking behavior and perceived stigma towards tuberculosis among tuberculosis suspects in a rural community in Southwest Ethiopia. PLoS One. 2010; 5 (10): e13339.

29. Biya O, Gidado S, Abraham A, Waziri N, Nguku P, Nsubuga P, et al. Knowledge, care-seeking behavior, and factors associated with patient delay among newly-diagnosed pulmonary tuberculosis patients, Federal Capital Territory, Nigeria, 2010. The Pan African Medical Journal. 2014; 18: 6. 